Agro-Science Journal of Tropical Agriculture, Food, Environment and Extension Volume 20 Number 1 (January 2021) pp. 95 - 102

ISSN 1119-7455

\title{
MANURIAL AMENDMENTS AND SOURCE OF WATER FOR SUPPLEMENTAL IRRIGATION OF SAWAH-RICE SYSTEM INFLUENCED SOIL QUALITY AND RICE YIELD
}

\author{
${ }^{1}$ Nnadi A.L., ${ }^{2}$ Ugwu V.U., ${ }^{3}$ Nwite J.C., ${ }^{* 2}$ Obalum S.E., ${ }^{2}$ Igwe C.A. and ${ }^{4}$ Wakatsuki T. \\ ${ }^{1}$ Department of Crop Science, University of Nigeria, Nsukka 410001, Nigeria \\ ${ }^{2}$ Department of Soil Science, University of Nigeria, Nsukka 410001, Nigeria \\ ${ }^{3}$ Department of Crop Production Technology, Federal College of Agriculture, PMB 7008, Ishiagu, Nigeria \\ ${ }^{4}$ Faculty of Life \& Environmental Sciences, Shimane University, Matsue-shi, Shimane 690-8504, Japan \\ *Corresponding author’s email address: sunday.obalum@unn.edu.ng
}

\begin{abstract}
Soil and water management research on adapting the promising sawah ecotechnology for lowland rice farming in West Africa has largely focused on the abundant inland valleys; floodplains which too represent a huge agricultural resource in the region have not been so involved. Sawah refers to a bunded, puddled and leveled basin for rice, with water inlets and outlets for irrigation and drainage, respectively. In conventional sawah, soil fertility is augmented using mineral fertilizers, with an option to harness lowland water resources for use in small-scale irrigation to create the so-called sawah typologies. In this study, we evaluated the effects of three

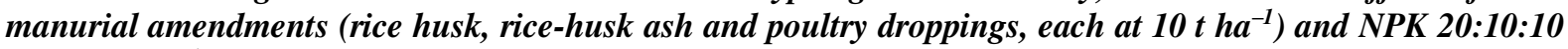
at $400 \mathrm{~kg} \mathrm{ha}^{-1}$ interacting with source of water (spring or pond) used for supplemental irrigation of three sawah typologies in a floodplain in southeastern Nigeria. Plots amended with poultry droppings and supplemented with spring water recorded the overall best performance of the sawah-rice system; the control being the unamended non-supplemented (solely rainfed) plots recorded the worst. Rice-husk ash and rice husk enhanced soil $\mathrm{pH}$ and soil organic carbon, respectively. The three sawah typologies showed a consistent trend thus spring-supplemented $\geq$ pond-supplemented $\geq$ non-supplemented sawah. Rice grain yield was influenced by soil total nitrogen and the sum of the three plant-nutrient basic cations $\left(\mathrm{K}^{+}, \mathrm{Ca}^{2+}\right.$ and $\left.\mathrm{Mg}^{2+}\right)$, with the influence of $\mathrm{K}^{+}$alone being the greatest. To enhance rice performance including grain yields in floodplain sawah, farmers should utilise poultry droppings as soil manure and spring water for supplemental irrigation.
\end{abstract}

Key words: lowland rice, sawah ecotechnology; floodplain soils, organic amendments, sawah typology, spring water

\section{INTRODUCTION}

The African adaptive lowland $s a w a h^{\dagger}$ system remains a highly promising platform for not just increasing rice (Oryza sativa) production but also attaining rice self-sufficiency in tropical Africa in a sustainable manner. Sawah-based rice farming is thus increasingly popular in especially West Africa where the relative abundance of such categories of lowland as inland valleys and floodplains is an advantage. Besides the fact that lowlands often are of higher soil fertility than adjacent uplands (Obalum et al., 2012a), they present favourable hydrological conditions for rice farming. Generally, floodplain soils show higher clay content and hence fertility status than inland-valley soils in West Africa (Abe et al., 2006); the reverse is true for topo-features that make for ease of water control.
Sawah has numerous agronomic and ecological benefits. It promotes the efficiency of soil and water management; conserves the fertility of lowland soils (nutrient-rich fine particles in the saturated puddled soils, alluvial flows and geo- and topo-accumulated water settle and build-up in the topsoil) and makes for proper harnessing of water and nutrients in the lowlands (Asubonteng et al., 2001; Wakatsuki and Masunaga, 2005). Considering that rice is a shallowrooting and water-loving grain crop, this improved environment for crop growth offered by lowland sawah often results in increased tillering potential and grain yield of rice (Obalum et al., 2014). For non-sawah fields (with uncontrolled flooding), these sediments elude the topsoil with the attendant hampering of rice growth and yield.

\footnotetext{
†Among researchers and farmers, the concept of sawah (a word that is of Malayo-Indonesian origin) is that of a lowland rice field after being systematically designed and prepared (bunded, puddled and leveled) in a such a way as to impound water in basins for ease of water control in the field. A typical sawah basin has valved water inlets and outlets on the bunds for irrigation and drainage, respectively, with all inlets usually connected to site-specific sources of water in the field for irrigating the basins by channel flow as and when needed. Sawah is further characterized by the growing of improved varieties of rice and the application of required mineral fertilizers at recommended rates.
}

Please cite as: Nnadi A.L., Ugwu V.U., Nwite J.C., Obalum S.E., Igwe C.A. and Wakatsuki T. (2021). Manurial amendments and source of water for supplemental irrigation of sawah-rice system influenced soil quality and rice yield. Agro-Science, 20 (1), 95-102. DOI: https://dx.doi.org/10.4314/as.v20i1.15 
Suitable amendments have been used to alleviate soil fertility-related constraints to crop growth in both inland valleys and floodplains of West Africa (Buri et al., 2008; Nwite et al., 2013; Tsujimoto et al., 2017), the aforenoted gradient in their inherent fertility status notwithstanding. This problem is both pedogenetic and anthropogenic, such that decreases in the amounts of weatherable minerals and the rate of their release are exacerbated by inappropriate soil and agronomic management practices, leading to widespread land degradation and yield losses (Obalum et al., 2012a). Without prejudice to the soil fertility conservation attribute of typical sawah-rice system relying solely on mineral fertilizers, there is a prospect in the use of manures in sawah whereby mineral fertilizers are partially or fully replaced with manurial amendments (Buri et al., 2004; Nwite et al., 2008, 2012).

Focusing on sawah-grown rice, there have also been reports of poor agronomic performance due to ineffective water control and inadequate water retention in sawah basins (Obalum et al., 2014). Lowland soil fertility cannot be effectively restored without compatible water control and management techniques. Sawah, being an ecotechnological farming system, could thus be used to concurrently address the duo of declining soil fertility and poor water management in lowland rice farming. This approach which defines integrated watershed management appears promising for sustainably increasing food production in tropical Africa (Hirose and Wakatsuki, 2002).

One way to boost the performance of sawah-rice system is use some locally generated agro-wastes with manurial value in restoring soil fertility in the marshy lowland soils. Also, because floodplains have the peculiar problem of fairly low amenability to water control, sawah-rice farming in this and similar categories of lowland should explore alternative sources of water in and around the rice field for supplemental irrigation. Small-scale irrigation using lowland water resources is farmer-operated, and this is economically more viable than reliance on heavy machineries with medium to large-sized pumps for irrigating several hundreds of hectares in West Africa (Wakatsuki, 1990; Obalum et al., 2011). However, lowland water resources for supplemental irrigation often differ in supplying capacity. They are bound to also differ in the amount of heat they are exposed to and the levels of organic and inorganic constituents in them, translating into differences in water quality (Haby and Pennington, 2003). These differences in quantity and quality among the waters for irrigation have prompted the use of the term 'sawah typologies' in sawah-based rice farming (Nwite et al., 2017).

The study by Nwite et al. (2017) involved three factors including manurial amendment type and sawah typology in a degraded soil of an inland-valley ecosystem in southeastern Nigeria. In the said study, the apparent differences in five soil amendment types (rice husk, rice-husk ash, poultry droppings, NPK fertilizer and a control) and three sawah typologies (spring-, pond- and non-supplemented) were reported to reflect in fertility of the inland-valley soil and rice grain yields, with the soil CEC having the dominant control over rice grain yield. Though floodplains are generally more fertile compared with inland valleys, water control is easier in the latter than the former (Abe et al., 2006; Obalum et al., 2011), suggesting that floodplains may respond to the treatments in Nwite et al. (2017) in patterns different from the ones reported from this reference study. This notion is, however, scarcely supported by empirical data at the moment. The objectives of the present study, therefore, were to (i) assess the potential of manurial amendment and source of water for supplemental irrigation for restoring the fertility sawah-managed floodplain soil in southeastern Nigeria, and (ii) evaluate any such effects on fertility parameters of the floodplain soil in terms of rice growth and yield.

\section{MATERIALS AND METHODS Site Description}

The experiment was conducted in the floodplain of Ivo River in Ishiagu, Ebonyi State, Nigeria, located on $06^{\circ} 25^{\prime} \mathrm{N}$ and $08^{\circ} 03^{\prime} \mathrm{E}$. The mean annual rainfall in the area is $1,350 \mathrm{~mm}$, spread from April to October with a mean air temperature of $29^{\circ} \mathrm{C}$. The floodplain soils belonging mostly to texture class of sandy loam are classified as Aeric Tropoaquent in Soil Taxonomy corresponding to Gleyic Cambisol in the FAO system. The underlying geologic material is Shale with sand intrusions locally called the 'Asu River' group. The site is in the derived savanna vegetation zone with grasses and shrub tree combinations. The floodplain soils are mainly used for rainfed rice farming and vegetable production as the rain recedes.

\section{Experimental Set-Up}

The field was demarcated into three main plots (each $9 \mathrm{~m} \times 37 \mathrm{~m}$ ) with $0.6-\mathrm{m}$ raised bunds for the treatments of small-scale irrigation using water from different sources. The three plots were maintained under rainfed conditions throughout the field study, such that the added irrigation water from different sources was merely supplemental. Thus the three main plots (treatments) representing three sawah typologies were designated spring-supplemented, pond-supplemented, and non-supplemented plots.

Spring-supplemented sawah was irrigated from a nearby spring (ca. $100 \mathrm{~m}$ away) connected to it by a constructed canal. Pond-supplemented sawah was irrigated from an artificial pond in the study site, from which water was delivered to the plots via a pumping machine with hose. Non-supplemented sawah was solely rainfed, and so served as the control. Overland flow into all main plots was guarded against using bunds. The small-scale irrigation treatments were investigated at three replications, achieved in this study by demarcation of each main plot into three equal blocks. 
To implement the five manurial treatments, each block representing replications of the main plots was further demarcated with bunds into sub-plots each measuring $2.65 \mathrm{~m} \times 7 \mathrm{~m}$. The five types of soil amendment were assigned to the sub-plots; they comprised rice-mill waste otherwise called rice husk (RH) applied at $10 \mathrm{t} \mathrm{ha}^{-1}$, partially burnt rice husk referred to as rice husk ash (RHA) applied at $10 \mathrm{t} \mathrm{ha}^{-1}$, $10 \mathrm{t} \mathrm{ha}^{-1}$, poultry droppings (PD) applied $10 \mathrm{t} \mathrm{ha}^{-1}$, NPK 20:10:10 fertilizer (NPK) applied $400 \mathrm{~kg} \mathrm{ha}^{-1}$, and no amendment as the control. The organic soil amendments (RH, RHA and PD) were spread on the plots and, using a garden fork, incorporated and properly mixed with the top- $(20 \mathrm{~cm})$ soil two weeks before rice transplanting. The mineral fertilizer (NPK) was applied two weeks after transplanting. From the foregoing, the experimental design in this study could be described as a split-plot in a 'partially' Randomized Complete Block Design (RCBD).

In the pond-supplemented sawah, a pumping machine with power output of $2.8 \mathrm{~kW}$, self-priming volute with 4 impeller blades and maximum discharge of 900 litres per minute, plus a total head of $26 \mathrm{M}$, was used to pump water into the field. The quantity of water applied to the spring- and pondsupplemented sawah was not measured; instead, water level in all the treatment basins of these two sawah typologies was maintained at $5-10 \mathrm{~cm}$ as from two weeks after transplanting until maturity, using installed sticks with bold marks at 5 and 10 $\mathrm{cm}$. The $0.6 \mathrm{~m}$ raised bunds helped to impound water and ensure that the defined water levels in the basins were maintained. The inlets and outlets to the plots were opened whenever the water level dropped below $5 \mathrm{~cm}$ or rose beyond $10 \mathrm{~cm}$, respectively.

\section{Pre-Planting Activities}

Before ploughing, soil samples were randomly taken from the topsoil, bulked into a composite sample and analysed for texture as well as for some key management-responsive physicochemical properties to determine their baseline values in the floodplain soil just before the study. This exercise showed that the soil, a sandy loam, had moderate soil organic carbon (SOC) concentration in the topsoil, while soil $\mathrm{pH}$ and cation exchange capacity (CEC) indicated low values, among other characteristics (Table 1).

A high-yielding variety of rice, Tox 3108 , widely used by farmers in the study area, was first raised in the nursery. Transplanting to the field was done four weeks later at a square $(20 \mathrm{~cm} \times 20 \mathrm{~cm})$ spacing. The plots were hoe-ploughed and manually puddled to ca. $20 \mathrm{~cm}$ depth before applying the treatments of this study. The RH used was collected from a ricemill industry close to the study site. Analyses of the manurial amendments (RH, RHA and PD) for their composition showed that RH had the highest content of organic carbon (C); RHA the highest phosphorus $(\mathrm{P})$, potassium $(\mathrm{K})$ and magnesium $(\mathrm{Mg})$; and $\mathrm{PD}$ the highest nitrogen $(\mathrm{N})$ and calcium $(\mathrm{Ca})$ (Table 2).
Table 1: Some properties of the top- $(0-20 \mathrm{~cm})$ soil at the study site before ploughing

\begin{tabular}{ll}
\hline Soil Properties & Value \\
\hline \% Clay & 10 \\
\% Silt & 21 \\
$\%$ Total sand & 69 \\
$\mathrm{pH}-\mathrm{H}_{2} \mathrm{O}$ & 3.7 \\
$\mathrm{pH}-\mathrm{KCl}$ & 1.7 \\
$\%$ Soil organic carbon & 1.42 \\
\% Total nitrogen & 0.09 \\
Available phosphorus $\left(\mathrm{mg} \mathrm{kg}^{-1}\right)$ & 4.30 \\
Exch. bases (cmol $\left.\mathrm{kg}^{-1}\right) ; \mathrm{K}^{+}$ & 0.08 \\
$\mathrm{Ca}^{2+}$ & 1.00 \\
$\mathrm{Mg}^{2+}$ & 1.56 \\
$\mathrm{Na}^{+}$ & 0.40 \\
Exchangeable acidity (EA) & 2.53 \\
Cation exchange capacity (CEC) & 8.22 \\
\hline
\end{tabular}

\section{Agronomic and Soil Data Collection}

At rice booting, data were collected on plant height and tillering by counting number of tillers per stand. At rice maturity, the rice plants harvested and dried, and grain yield assessed at $90 \%$ dry matter content. Also, soil samples were collected from the replicates of the treatments. They were air-dried to constant weight and passed through a 2-mm sieve. These processed samples were analysed for soil $\mathrm{pH}, \mathrm{SOC}$, total nitrogen using standard laboratory methods as already chronicled in Nwite et al. (2017); soil pH by measuring in suspensions of soil in deionised $\mathrm{H}_{2} \mathrm{O}$ and $0.1 \mathrm{~N} \mathrm{KCl}$ in soil-liquid mass ratio of $1: 2.5$, SOC by the Walkley-Black method; and total nitrogen by Kjeldahl digestion-distillation and titration method. Additionally, soil contents of the three plant-nutrient exchangeable bases (basic cations) including $\mathrm{K}^{+}$, $\mathrm{Ca}^{2+}$ and $\mathrm{Mg}^{2+}$ were determined following the procedure described by Thomas (1982).

\section{Data Analysis}

Data were subjected to analysis of variance procedure appropriate for a split-plot experiment in an RCBD using the software GenStat Edition 3 version 7.2 (VSN International, Hemel Hempstead, UK). Significant treatment means were separated and compared by the least significant difference (LSD). In addition, rice growth and grain yield were related to the soil fertility parameters determined at rice maturity irrespective of treatment. This was done by Pearson correlations using the software SPSS for Windows (IBM SPSS Statistics 21.lnk) and by pairwise regressions using the Microsoft Excel sheet. All inferences were made at the 5\% probability level.

Table 2: Compositions (\%) of the manurial amendments

\begin{tabular}{lccc}
\hline Property & Rice husk & Rice-husk ash & Poultry droppings \\
\hline $\mathrm{C}$ & 33.75 & 3.89 & 16.52 \\
$\mathrm{~N}$ & 0.700 & 0.056 & 2.100 \\
$\mathrm{P}$ & 0.49 & 11.94 & 2.55 \\
$\mathrm{~K}$ & 0.11 & 1.77 & 0.48 \\
$\mathrm{Ca}$ & 0.36 & 1.40 & 14.40 \\
$\mathrm{Mg}$ & 0.38 & 5.00 & 1.20 \\
$\mathrm{Na}$ & 0.22 & 0.33 & 0.34 \\
$\mathrm{C}: \mathrm{N}$ & 48.21 & 6.71 & 7.87 \\
\hline
\end{tabular}




\section{RESULTS AND DISCUSSION \\ Treatment Effects on Soil pH, Soil Organic Carbon and Total Nitrogen}

The interaction effects of the manurial amendments and water sources for the small-scale supplemental irrigation on the soil $\mathrm{pH}$ as well as SOC and total nitrogen concentrations in the topsoil of the sawahmanaged floodplain soil are shown in Table 3. Treatment affected soil $\mathrm{pH}$, with highest values in RHA-amended spring- or pond-supplemented plots and lowest values in unamended non-supplemented plots. Averaged across sawah typologies, soil pH was higher in RHA-amended plots than the rest. This observation portrays the soil liming effect of RHA (Nwite et al., 2013). Ash contains oxides as hydroxides of calcium, magnesium, potassium and, to a lesser extent, sodium (Lickacz, 2002); therefore, RHA being similar to burnt or hydrated lime in its mode of action it is not surprising. Contrary to these effects of RHA on soil $\mathrm{pH}$, Nnabude and Mbagwu (2001) noted that production of organic acids during the decomposition of burnt rice wastes as well as the evolution of $\mathrm{CO}_{2}$ during the same process could decrease soil $\mathrm{pH}$. During the preparation of RHA in the present study, the proportion of rice husk that was not converted into RHA but merely steamed was probably very small; so, applying the RHA to the soil resulted in its liming value dominating over the effect of decomposition of the steamed RH. Sawah typology influenced soil $\mathrm{pH}$ thus spring-supplemented $>$ pond-supplemented > non-supplemented plots. This could be attributed to the higher $\mathrm{pH}$ often found of spring than pond water (Nwite et al., 2017), as well as to depositions of organic materials and soil minerals by the flowing water from the spring.

The concentration of SOC in the sawah-managed floodplain showed highest values in RH-amended spring- or pond-supplemented plots and lowest values in RHA- and NPK-amended non-supplemented plots. Averaged across sawah typologies, SOC tended to be highest in RH-amended plots and lowest in RHAand NPK-amended plots. This is unsurprising as RH is highly carbonaceous with relatively small amount of nitrogen (Adubasim et al., 2018), implying high $\mathrm{C}-\mathrm{N}$ ratio. The $\mathrm{C}-\mathrm{N}$ ratio of the $\mathrm{RH}$ used in this study was indeed high (48.21), such that the associated high lignin content and low polyphenol content must have retarded its rate of decomposition in the soil (Schulz et al. 2003), especially with the submerged condition of the soil during most of the rice growth phase (Nwite et al., 2017). The low SOC in RHAamended plots reflected the phenomenon whereby carbon and nitrogen in the RH were lost in form of gases to the atmosphere during burning.

Among the sawah typologies, SOC tended to decrease from spring-supplemented through pondsupplemented to non-supplemented plots. This trend reflected the relative frequency of wetting-drying cycles in these typologies during rice growth phase, expected to be highest in non-supplemented sawah.
In their study of physicochemical properties of topsoils of inland-valley sawah fields at various locations in north-central Nigeria, Obalum et al. (2012b) reported higher concentrations of SOC in a bottom slope position with well-defined submergence compared to upper slope positions with negligible submergence at Nasarafu - one of their study locations. Waterlogging hampers microbial activity and decomposition of organic materials in the soil but frequent wetting-drying cycles in waterlogged soils facilitates SOC decomposition, which implies lowering of its content in the soil (Nwite et al., 2017). Considering the place of SOC in soil quality (Obalum et al., 2017), sawah-rice farming in this floodplain soil should involve the use of RH as soil amendment and prolonging of submergence time in order to improve the quality of the soil.

Soil total nitrogen content showed highest values in PD-amended spring- or non-supplemented plots and lowest values in RH-amended and unamended non-supplemented plots. Averaged across sawah typologies, total nitrogen tended to be higher in PD- and NPK-amended plots than the rest. The RH could not improve total nitrogen, an observation attributed to the short-term nature of this field study vis-à-vis the slow rate of $\mathrm{RH}$ mineralization in the soil (Nwite et al., 2017). As with SOC, total nitrogen tended to decrease from spring-supplemented through pond-supplemented to non-supplemented plots. Since enhanced soil water status could increase biological nitrogen fixation (Buresh et al., 2008), the trend observed of soil total nitrogen could be said to reflect the relative extents of water retention and submergence among the sawah topologies during the rice growth phase (Obalum et al., 2012b).

\section{Treatment Effects on Soil Contents of Plant-Nutrient Exchangeable Bases}

The interaction effects of the manurial amendments and water sources for the small-scale supplemental irrigation on the contents of the three plant-nutrient exchangeable bases in the topsoil of the sawahmanaged floodplain soil are shown in Table 4. Treatment affected exchangeable potassium $\left(\mathrm{K}^{+}\right)$ and calcium $\left(\mathrm{Ca}^{2+}\right)$ in a somewhat similar manner, in that their highest values were found in RHA- and PD-amended plots of spring-and pond-supplemented sawah and their lowest values in the unamended (control) plots also of both spring-and pondsupplemented sawah. When checked for the effects of soil amendments across sawah typologies, these two basic cations $\left(\mathrm{K}^{+}\right.$and $\left.\mathrm{Ca}^{2+}\right)$ decreased in the same pattern; from RHA-amended to control plots.

For exchangeable magnesium $\left(\mathrm{Mg}^{2+}\right)$, the highest values were found in RHA-amended plots of all three sawah typologies (and these values were similar only to that found in PD-amended springsupplemented sawah), and lowest values in RHamended and control plots of spring- and/or pondsupplemented sawah. Across the sawah typologies, 
Table 3: Interaction effects of manurial amendments and water sources for the small-scale supplemental irrigation on the soil $\mathrm{pH}$ as well as SOC and total nitrogen contents in the topsoil of sawah-managed floodplain soil at Ishiagu, southeastern Nigeria

\begin{tabular}{|c|c|c|c|c|c|c|c|c|c|c|c|c|}
\hline \multirow[t]{2}{*}{ Soil amendments } & \multicolumn{4}{|c|}{ Soil pH } & \multicolumn{4}{|c|}{$\%$ Soil organic carbon (SOC) } & \multicolumn{4}{|c|}{$\%$ Total nitrogen } \\
\hline & SSS & PSS & NSS & Mean & SSS & PSS & NSS & Mean & SSS & PSS & NSS & Mean \\
\hline Rice husk (RH) & 5.6 & 5.0 & 4.8 & 5.1 & 1.09 & 0.92 & 0.72 & 0.91 & 0.068 & 0.060 & 0.047 & 0.058 \\
\hline Rice-husk ash (RHA) & 6.2 & 6.1 & 5.6 & 6.0 & 0.82 & 0.61 & 0.43 & 0.62 & 0.062 & 0.059 & 0.055 & 0.059 \\
\hline Poultry droppings (PD) & 5.1 & 4.9 & 4.6 & 4.9 & 0.87 & 0.72 & 0.62 & 0.74 & 0.080 & 0.073 & 0.082 & 0.078 \\
\hline NPK 20:10:10 (NPK) & 5.2 & 4.8 & 4.5 & 4.8 & 0.64 & 0.68 & 0.48 & 0.60 & 0.074 & 0.078 & 0.070 & 0.074 \\
\hline Control & 4.8 & 4.8 & 4.3 & 4.6 & 0.90 & 0.66 & 0.52 & 0.69 & 0.055 & 0.060 & 0.050 & 0.055 \\
\hline Mean & 5.4 & 5.1 & 4.8 & & 0.86 & 0.71 & 0.55 & & 0.081 & 0.066 & 0.060 & \\
\hline $\operatorname{LSD}_{(0.05)}$ & & 0.22 & & & & 0.18 & & & & 0.012 & & \\
\hline
\end{tabular}

Table 4: Interaction effects of manurial amendments and water sources for the small-scale supplemental irrigation on topsoil contents of the three plant-nutrient exchangeable bases in the sawah-managed floodplain soil at Ishiagu, southeastern Nigeria

\begin{tabular}{|c|c|c|c|c|c|c|c|c|c|c|c|c|}
\hline \multirow[t]{2}{*}{ Soil amendments } & \multicolumn{4}{|c|}{ Exchangeable potassium $\left(\mathrm{K}^{+}\right)$} & \multicolumn{4}{|c|}{ Exchangeable calcium $\left(\mathrm{Ca}^{2+}\right)$} & \multicolumn{4}{|c|}{ Exchangeable magnesium $\left(\mathrm{Mg}^{2+}\right)$} \\
\hline & SSS & PSS & NSS & Mean & SSS & PSS & NSS & Mean & SSS & PSS & NSS & Mean \\
\hline Rice husk (RH) & 0.15 & 0.12 & 0.13 & 0.13 & 2.00 & 2.00 & 1.73 & 1.91 & 0.93 & 0.98 & 1.07 & 0.99 \\
\hline Rice-husk ash (RHA) & 0.26 & 0.27 & 0.21 & 0.25 & 3.23 & 2.98 & 1.98 & 2.73 & 2.00 & 2.00 & 2.11 & 2.04 \\
\hline Poultry droppings (PD) & 0.24 & 0.26 & 0.20 & 0.23 & 2.52 & 2.52 & 1.93 & 2.32 & 1.87 & 1.67 & 1.27 & 1.60 \\
\hline NPK 20:10:10 (NPK) & 0.22 & 0.22 & 0.17 & 0.20 & 1.87 & 1.90 & 1.80 & 1.86 & 1.47 & 1.41 & 1.27 & 1.38 \\
\hline Control & 0.09 & 0.10 & 0.10 & 0.10 & 1.47 & 1.33 & 1.73 & 1.51 & 0.93 & 1.10 & 1.11 & 1.05 \\
\hline Mean & 0.19 & 0.19 & 0.16 & & 2.22 & 2.14 & 1.83 & & 1.44 & 1.43 & 1.36 & \\
\hline $\operatorname{LSD}_{(0.05)}$ & & & & & & 0.36 & & & & 0.30 & & \\
\hline
\end{tabular}

the soil amendments differed in the same pattern as for $\mathrm{K}^{+}$and $\mathrm{Ca}^{2+}$ except for the lowest values in $\mathrm{RH}-$ amended plots instead of the control plots. Thus all three plant-nutrient exchangeable bases of this study followed the order RHA > PD > NPK > the other two treatments. The consistently highest values of these three basic cations in RHA-amended plots would be largely explained by RHA's content of potassium, calcium and magnesium hydroxides (Lickacz, 2002). In a similar study in two inlandvalley soils in southeastern Nigeria with a similar set and source of soil amendments applied at the same rates as the present study, but with RHA of lower quality compared to the present study, the order was $\mathrm{NPK}>\mathrm{PD} \geq \mathrm{RHA}$ for $\mathrm{K}^{+}$and $\mathrm{PD}>\mathrm{RHA} \geq \mathrm{NPK}$ for $\mathrm{Ca}^{2+}$ and $\mathrm{Mg}^{2+}$ in the two locations (Igwe et al., 2013). These contrasting observations put together, we infer that the effects of RHA, relative to other organic and inorganic fertilizers, on plant-nutrient exchangeable bases in sawah-managed lowland soils would depend on the lowland type (inland valley or floodplain), quality of the RHA, and the basic cation of interest.

One other consistent observation is that the main effects of sawah typology showed higher levels of all three plant-nutrient exchangeable bases in both spring- and pond-supplemented sawah compared to non-supplemented sawah (Table 4). As opposed to the negative correlations found between soil $\mathrm{pH}$ and the exchangeable bases for some inland-valleys soils (Obalum et al., 2012b), soil $\mathrm{pH}$ correlated positively with soil contents of the trio of $\mathrm{K}^{+}, \mathrm{Ca}^{2+}$ and $\mathrm{Mg}^{2+}$ ( $r=0.574,0.741$ and 0.634 , respectively) of the floodplain soil under investigation. The influence of sawah typology on these basic cations thus partially reflect the influence of water source for the smallscale supplemental irrigation on soil $\mathrm{pH}$. Further, although the spring and pond water of this study were not analysed for their potassium, calcium and magnesium contents, the former probably had higher contents of these nutrient elements than the latter, thus partially explaining the observation made.

Notably, amending this floodplain soil with RHA was rather ineffectual for soil total nitrogen but not the three plant-nutrient exchangeable bases. This observation supports Saggar et al. (1990) and Nwite et al. (2013) that ash-amended soils could show increases in other nutrients but not nitrogen.

Treatment Effects on Plant Height, Tillering Ability and Grain Yield of the Sawah-Grown Rice Table 5 shows the agronomic effects of the manurial amendments and source of water used to irrigate the sawah typologies, evaluated by the growth attributes (plant height and number of tillers per stand) of rice at booting as well as its grain yield at maturity. The tallest rice plants were recorded in PD-amended spring-supplemented sawah. This was followed by RHA- or NPK-amended spring-supplemented sawah which in turn was followed by PD- or NPK-amended pond-supplemented sawah. Number of tillers per stand was highest in PD-amended plots except in the non-supplemented sawah. The shortest plants and fewest tillers were found in the overall control (unamended non-supplemented sawah). For these growth attributes, the main effects of sawah typology were not evident; those of soil amendment showed PD-amended plots as surpassing NPK-amended plots, with the lowest values in the control plots. 
Table 5: Interaction effects of manurial amendments and water sources for the small-scale supplemental irrigation on plant height, tillering and grain yield of rice grown in the sawah-managed floodplain soil at Ishiagu, southeastern Nigeria

\begin{tabular}{|c|c|c|c|c|c|c|c|c|c|c|c|c|}
\hline \multirow[t]{2}{*}{ Soil amendments } & \multicolumn{4}{|c|}{ Plant height $(\mathrm{cm})$} & \multicolumn{4}{|c|}{ Number of tillers per stand } & \multicolumn{4}{|c|}{ Grain yield $\left(\mathrm{t} \mathrm{ha}^{-1}\right)$} \\
\hline & SSS & PSS & NSS & Mean & SSS & PSS & NSS & Mean & SSS & PSS & NSS & Mean \\
\hline Rice husk (RH) & 42.55 & 39.73 & 38.6 & 40.29 & 14.40 & 14.34 & 13.28 & 14.01 & 6.56 & 6.00 & 6.07 & 6.21 \\
\hline Rice-husk ash (RHA) & 43.89 & 40.47 & 39.33 & 41.23 & 13.80 & 13.75 & 12.66 & 13.40 & 6.56 & 6.38 & 6.08 & 6.34 \\
\hline Poultry droppings (PD) & 46.71 & 43.34 & 42.24 & 44.10 & 15.74 & 15.36 & 13.55 & 14.88 & 7.82 & 6.56 & 6.10 & 6.83 \\
\hline NPK 20:10:10 (NPK) & 43.70 & 43.82 & 40.69 & 42.74 & 14.20 & 14.17 & 13.84 & 14.07 & 7.11 & 6.28 & 6.30 & 6.56 \\
\hline Control & 33.99 & 36.98 & 33.22 & 34.73 & 11.78 & 11.78 & 11.78 & 11.78 & 4.68 & 4.59 & 4.26 & 4.51 \\
\hline Mean & 42.17 & 40.87 & 38.62 & & 13.98 & 13.88 & 13.02 & & 6.55 & 5.69 & 5.56 & \\
\hline $\operatorname{LSD}_{(0.05)}$ & \multicolumn{4}{|c|}{0.75} & \multicolumn{4}{|c|}{0.03} & \multicolumn{4}{|c|}{0.36} \\
\hline
\end{tabular}

Rice grain yield was highest and second highest in PD- and NPK-amended spring-supplemented sawah, respectively, while lowest in the overall control (Table 5). Main effect of sawah typology was higher yield in spring- than pond- and non-supplemented sawah for which values were similar. Sawah basins when submerged often shows improvements in soil porosity, hydraulic properties and hence rice yields (Obalum et al., 2012c; Nwite et al., 2016). Since both spring- and pond-supplemented sawah were similarly submerged here, the former out-yielding the latter suggests that there is more to rice yields than any such improvements in this floodplain. Nwite et al. (2017) found no differences in rice yield among these three sawah typologies in an inland valley in southeastern Nigeria, but showed the importance of 'completely' prepared sawah in discriminating between springand pond- supplemented plots. And such intensity of sawah preparation was adopted here. The higher yield in the spring- than pond-supplemented sawah may thus be explained by the higher contents of nutrients in the spring than pond water earlier alluded to.

The soil amendments ranked thus $\mathrm{PD} \geq \mathrm{NPK} \geq$ RHA $\geq$ RH $>$ control. Ofori et al. (2005) showed the positive role of optimum level of inputs in the form of soil amendment in rice yield responses to good water management practices under the sawah system. Though the order of effects of the soil amendments in the present study in a floodplain was fairly different from that in Nwite et al. (2017) in an inland valley, both studies showed the preference of PD to NPK and indeed RHA and RH for sawah rice. By contrast, Buri et al. (2004) reported lower grain yields of lowland sawah rice in PD- than NPK-amended plots in two out of three locations within the forest ecology of Ghana. Besides the differences in ecological setting, it should be noted that Buri et al. (2004) applied PD at a rate $\left(7 \mathrm{tha}^{-1}\right)$ lower than the rate here $\left(10 \mathrm{tha}^{-1}\right)$, but N-P-K at a rate (90-60-60 $\mathrm{kg} \mathrm{ha}^{-1}$ ) higher than ours (the NPK 20:10:10 applied at $400 \mathrm{~kg} \mathrm{ha}^{-1}$ here corresponds to N-P-K at $80-40-40 \mathrm{~kg} \mathrm{ha}^{-1}$ ).

Notably, the lowest grain yield due to the overall control $\left(4.26 \mathrm{t} \mathrm{ha}^{-1}\right)$ is rather high when related to the values in the range of 1.50-2.60 $\mathrm{t} \mathrm{ha}^{-1}$ reported for some corresponding inland-valley sawah systems (Buri et al., 2004; Nwite et al., 2017). Thus under similar sawah water management, floodplains may produce higher than inland valleys in West Africa.

\section{Relationships between Rice Performance and Soil Fertility Parameters of the Study}

Table 6 shows the relationships between the indices of rice performance (growth attributes and grain yield) and soil fertility parameters at rice maturity. None of these indices correlated with soil $\mathrm{pH}$ and SOC, but they generally correlated with total nitrogen, the three plant-nutrient exchangeable bases, and their sum. The correlation coefficients $(r)$ show that the relationships between plant height and each of total nitrogen and $\mathrm{K}^{+}$were similar and stronger than those established with $\mathrm{Ca}^{2+}, \mathrm{Mg}^{2+}$ and the sum of these cations. Number of tillers per stand followed suit. For grain yield, however, it was the strengths of its correlations with total nitrogen and the sum of the three basic cations that were similar, lower than that for $\mathrm{K}^{+}$.

When the yield was regressed on total nitrogen and the sum of the three basic cations, the best form of the regressions showing greater ability of the latter than the former to predict grain yield was polynomial (Figure 1). This aligns to the dominant influence of soil CEC on yield of sawah rice (Nwite et al., 2017). Specifically, Witt et al. (2005) showed the roles of the three basic cations in promoting the yields of intensively irrigated lowland rice.

The facts that yield had stronger correlation with $\mathrm{K}^{+}$alone than with the three basic cations summed up and that the yield could vary in a quadratic manner with these basic cations manifested when the yield was regressed separately on each of them (Figure 2). Thus of all soil fertility parameters here, $\mathrm{K}^{+}$is the best predictor of yield of floodplain sawahgrown rice, there are threshold values of these basic cations beyond which grain yield declines. For $\mathrm{K}^{+}$, this value is, as shown by the dotted line in Figure 2, ca. $0.224 \mathrm{cmol} \mathrm{kg}^{-1}$. This value is within the generic range of low $\mathrm{K}^{+}$in Nigerian soils (Chude et al., 2011), and so may not represent management-target value of $\mathrm{K}^{+}$in lowland sawah-rice system. Instead, we interpret the results to be due to a linear positive relationship between soil $\mathrm{K}^{+}$balance and rice uptake in the various treatments. This is based on the knowledge that rice grain yield often tends to decline beyond K-fertilizer rate of $60 \mathrm{~kg} \mathrm{ha}^{-1}$ (Buri et al., 2008) or certain levels of $\mathrm{K}^{+}$uptake (Islam et al., 2015; Jiang et al., 2019). As with grain yield, plant height and number of tillers per stand both showed quadratic relationships with the three basic cations (figure not shown). 
Table 6: Coefficients of the correlations of rice growth and yield with some fertility parameters of the sawah-managed floodplain soil under various manurial amendments and supplemental irrigation water sources at Ishiagu, southeastern Nigeria $(n=15)$

\begin{tabular}{|c|c|c|c|c|c|c|c|}
\hline & \multirow{2}{*}{$\begin{array}{c}\text { Soil } \\
\mathrm{pH}\end{array}$} & \multirow{2}{*}{$\begin{array}{l}\text { Soil organic carbon } \\
\text { (SOC) }\end{array}$} & \multirow{2}{*}{$\begin{array}{c}\text { Total } \\
\text { nitrogen }\end{array}$} & \multicolumn{4}{|c|}{ Plant-nutrient exchangeable bases (basic cations) } \\
\hline & & & & $\mathrm{K}^{+}$ & $\mathrm{Ca}^{2+}$ & $\mathrm{Mg}^{2+}$ & $\mathrm{K}^{+}+\mathrm{Ca}^{2+}+\mathrm{Mg}^{2+}$ \\
\hline Plant height & $0.386^{\mathrm{ns}}$ & $0.222^{\mathrm{ns}}$ & $0.782^{* * * *}$ & $0.787^{* * * *}$ & $0.578^{*}$ & $0.500^{\dagger}$ & $0.598^{*}$ \\
\hline No. of tillers per stand & $0.242^{\mathrm{ns}}$ & $0.348^{\mathrm{ns}}$ & $0.674^{* *}$ & $0.661^{* *}$ & $0.558^{*}$ & $0.336^{\mathrm{ns}}$ & $0.505^{\dagger}$ \\
\hline Grain yield & $0.435^{\mathrm{ns}}$ & $0.208^{\mathrm{ns}}$ & $0.623^{*}$ & $0.757^{\text {*** }}$ & $0.583^{*}$ & $0.524^{*}$ & $0.610^{*}$ \\
\hline
\end{tabular}

ns - not significant; ${ }^{\dagger}$ marginally significant (at $10 \%$ probability level); $*{ }^{* *}$ and $* * *$ significant at 5,1 and $0.10 \%$ probability levels, respectively
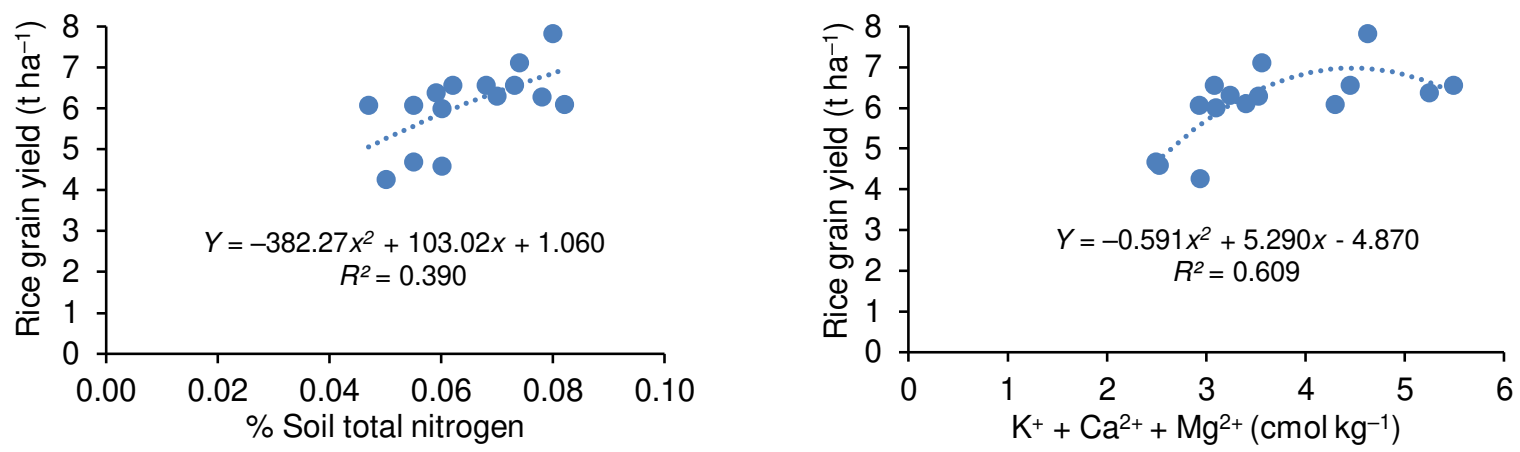

Figure 1: Relationships of rice grain yield with soil total nitrogen and sum of the three plant-nutrient exchangeable bases
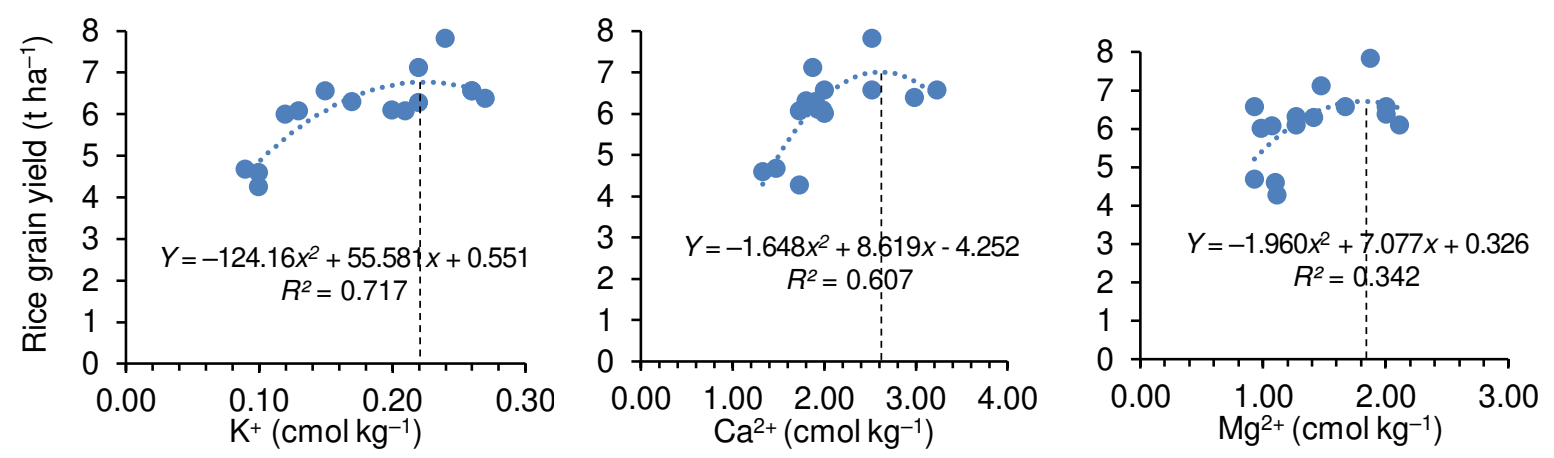

Figure 2: Relationships of rice grain yield with soil content of each of the three plant-nutrient exchangeable bases

\section{CONCLUSIONS}

The floodplain soil of this study was rather low in soil $\mathrm{pH}$ and poor in key plant nutrients. Within the modified rice-growing environment offered by the lowland sawah platform, the topsoil responded well to the manurial soil amendments and small-scale supplemental irrigation using spring and pond water. The overall best results for soil fertility parameters as well as for rice growth and grain yield were from plots with PD as manurial amendment and spring as source of water for the supplemental irrigation. The use of RHA was particularly effective in alleviating the acidity problem of the floodplain soil, while RH enhanced its SOC status and hence overall quality more than the other soil amendments. However, rice performance including grain yield was not influenced by soil $\mathrm{pH}$ and SOC, but by total nitrogen and the sum of the three plant-nutrient basic cations, with the influence of $\mathrm{K}^{+}$alone being the greatest.

By implication, 'locally adapted sawah' utilising $\mathrm{PD}$ as soil manure and receiving extra water from available spring would be preferred to 'conventional' NPK-fertilized and rainfed sawah in floodplain rice farming. Research should explore the exact roles of the plant-nutrient basic cations especially $\mathrm{K}^{+}$in the productivity of lowland sawah-rice systems under contrasting soil and water management practices.

\section{ACKNOWLEDGEMENT}

The study was done under the New Sawah Project - Nigeria, previously funded through Kinki (now Kindai) University of Japan by the Japan Society for the Promotion of Science (JSPS). The authors appreciate the on-the-job trainings on the management of the many inland valleys and floodplains in West Africa as well as the technical support provided by this New Sawah Project, led by one of them (Wakatsuki T.), at various times before and during the study.

\section{REFERENCES}

Abe S.S., Masunaga T., Yamamoto S., Honna T. and Wakatsuki T. (2006). Comprehensive assessment of the clay mineralogical composition of lowland soils in West Africa. Soil Sci. Plant Nutr., 52, 479-488

Adubasim C.V., Igwenagu C.M., Josiah G.O., et al. (2018). Substitution of manure source and aerator in nursery media on sandy-loam topsoil and their fertility indices 4 months after formulation. Int. J. Recycl. Org. Waste Agric., 7 (4), 305-312. DOI: 10.1007/s40093-018-0216-8

Asubonteng K.O., Kubota D., Hayashi K., Masunaga T., Otoo E. and Wakatsuki T. (2001). Effect of a sawah-based farming system on rice cultivation in the inland valley bottom of the Ashanti region of Ghana. Tropics, 10 (4), 555-564

Buresh R.J., Reddy K.R. and van Kessel C. (2008). Nitrogen transformations in submerged soils. In: Schepers J.S. and Raun W.R. (eds.), Nitrogen in Agricultural Systems. Agronomy Monograph no. 49 (pp. 401-436). American Soc. Agron., Crop Sci. Soc. America, \& Soil Sci. Soc. America, Madison, WI 
Buri M.M., Issaka R.N. and Wakatsuki T. (2008). Determining optimum rates of mineral fertilizers for economic rice grain yields under the "sawah" system in Ghana. West Afr. J. Appl. Ecol., 12 (1), 19-31

Buri M.M., Issaka R.N., Wakatsuki T. and Otoo E. (2004). Soil organic amendments and mineral fertilizers: options for sustainable lowland rice production in the forest agroecology of Ghana. Agric. Food Sci. J. Ghana, 3, 237-248

Chude V.O., Olayiwola S.O., Osho A.O. and Daudu C.K. (eds.) (2011). Fertilizer Use and Management Practices for Crops in Nigeria, $4^{\text {th }}$ edn. (p. 43). Fertilizer Procurement and Distribution Division (FPDD), Federal Ministry of Agric. \& Rural Dev., Abuja

Haby V.A. and Pennington H.D. (2003). Irrigation water source and quality. In: Texas M.L., Blueberry Handbook - Production and Marketing (pp. 106-221). Texas Agric. Extension Services, College Station, Texas

Hirose S. and Wakatsuki T. (2002). Restoration of Inland Valley Ecosystems in West Africa (pp. 71-73). Assoc. Agric. \& Forestry Statistics, Tokyo, Japan

Igwe C.A., Nwite J.C., Agharanya K.U., et al. (2013). Aggregate-associated soil organic carbon and total nitrogen following amendment of puddled and sawahmanaged rice soils in southeastern Nigeria. Archives Agron. Soil Sci., 59 (6), 859-874. https://doi.org/10. 1080/03650340.2012.684877

Islam A., Chandrabiswas J., Karim A.J.M.S, Salmapervin and Saleque A. (2015). Effects of potassium fertilization on growth and yield of wetland rice in grey terrace soils of Bangladesh. Res. Crop Ecophysiol., 10/2 (2), 64-82

Jiang W., Wang X., Xing Y., Liu X., Cui Z. and Yang L. (2019). Enhancing rice production by potassium management: recommended reasonable fertilization strategies in different inherent soil productivity levels for a sustainable rice production system. Sustainability, 2019, 11, 6522; DOI: $10.3390 /$ su11226522

Lickacz J. (2002). Wood ash: an alternative liming material for agricultural soils. Alberta Agric., Food \& Rural Dev. https://open.alberta.ca/publications/2616494

Nnabude P.C. and Mbagwu J.S.C. (2001). Physicochemical properties and productivity of a Nigerian Typic-Haplustult amended with fresh and burnt ricemill wastes. Bioresour. Technol., 76, 265-272

Nwite J.C., Igwe C.A. and Wakatsuki T. (2008). Evaluation of sawah rice management system in an inland valley in southeastern Nigeria. I: soil chemical properties and rice yield. Paddy Water Environ., 6, 299-307. DOI: 10.1007/s10333-008-0123-0

Nwite J.C., Keke C.I., Obalum S.E., Essien J.B., Anaele M.U. and Igwe C.A. (2013). Organo-mineral amendment options for enhancing soil fertility and nutrient composition and yield of fluted pumpkin. Int. J. Vegetable Sci., 19 (2), 188-199. https://doi.org/10. 1080/19315260.2012.705233

Nwite J.C., Obalum S.E., Igwe C.A. and Wakatsuki T. (2016). Soil physical properties and grain yields of lowland rice in response to sawah preparation intensities and soil amendment types. Biol. Agric. Hort., 32 (3), 192-205. https://doi.org/10.1080/01448765.2016.1152507

Nwite J.C., Obalum S.E., Igwe C.A. and Wakatsuki T. (2017). Interaction of small-scale supplemental irrigation, sawah preparation intensity and soil amendment type on productivity of lowland sawahrice system. South Afr. J. Plant Soil, 34 (4), 301-310. https://doi.org/10.1080/ 02571862.2017.1309468

Nwite J.C., Obalum S.E., Igwe C.A., et al. (2012). Sawah rice system, a technology for sustainable rice production and soil chemical properties improvement in Ebonyi State of Southeastern Nigeria. World J. Agric. Sci., 8 (4), 351-358
Obalum S.E., Buri M.M., Nwite J.C., et al. (2011). Farmers' personal irrigated sawah systems: an approach to realizing lowland rice potential and green revolution in sub-Saharan Africa. Presented under Fundamental for Life: Soil, Crop, and Environmental Sciences, the ASA-CSSA-SSSA Int. Annual Meetings, 16-19 Oct., 2011, San Antonio, Texas

Obalum S.E., Buri M.M., Nwite J.C., et al. (2012a). Soil degradation-induced decline in productivity of subSaharan African soils: the prospects of looking downwards the lowlands with the sawah ecotechnology. Applied Environ. Soil Sci., Vol. 2012, Article ID 673926, 10 pp. DOI: 10.1155/2012/673926

Obalum S.E., Chibuike G.U., Peth S. and Ouyang Y. (2017). Soil organic matter as sole indicator of soil degradation. Environ. Monitoring Assessment, 189 (4), Article 176. DOI: $10.1007 / \mathrm{s} 10661-017-5881-y$

Obalum S.E., Nwite J.C., Watanabe Y., Igwe C.A. and Wakatsuki T. (2012b). Comparative topsoil characterization of sawah rice fields in selected inland valleys around Bida, north-central Nigeria: physicochemical properties and fertility status. Trop. Agric. Dev., 56 (2), 39-48. https://doi.org/10.11248/jsta.56.39

Obalum S.E., Oppong J., Nwite J.C., et al. (2012c). Longterm effects of lowland sawah system on soil physicochemical properties and rice yield in Ashanti Region of Ghana. Spanish J. Agric. Res., 10 (3), 838-848. http://dx.doi.org/10.5424/sjar/2012103-566-11

Obalum S.E., Watanabe Y., Igwe C.A., Obi M.E. and Wakatsuki T. (2014). Puddling intensity for late-season sawah systems based on soil hydrophysical conditions and rice performance. Int. Agrophy, 28 (3), 331-340. DOI: 10.2478 /intag-2014-0023

Ofori J., Hisatomi Y., Kamidouzono A., Masunaga T. and Wakatsuki T. (2005). Performance of rice cultivars in various sawah ecosystems developed in inland valleys, Ashanti region, Ghana. Soil Sci. Plant Nutr., 51, 469-476

Saggar S., Hedley M.J. and White R.E. (1990). A simplified resin membrane technique for extracting phosphorus from soil. Fertilizer Res., 24, 173-180

Schulz S., Tian G., Oyewole B. and Bako S. (2003). Rice mill waste as organic manure on a degraded Alfisol. Agric. Ecosys. Environ., 100, 221-230

Thomas G.W. (1982). Exchangeable cations. In: Page A.L. (ed.) Methods of Soil Analysis, Part 2 (pp. 159-165). America Soc. Agron., Madison, WI

Tsujimoto Y., Inusa B., Katsura K., et al. (2017). The effect of sulfur fertilization on rice yields and nitrogen use efficiency in a floodplain ecosystem of northern Ghana. Field Crops Res., 211, 155-164. DOI: 10.1016/j.fcr.2017.06.030

Wakatsuki T. (1990). Distribution and characteristics of lowland soils and agricultural development in tropical Africa. In: Kiuchi T. (ed.), Soil Resources in Tropical Africa (pp. 86-113), Association for International Cooperation of Agriculture \& Forestry (AICAF), Tokyo

Wakatsuki T. and Masunaga T. (2005). Ecological engineering for sustainable food production of degraded watersheds in tropics of low $\mathrm{pH}$ soils: focus on West Africa. Soil Sci. Plant Nutr., 51, 629-636

Wakatsuki T., Otoo E., Andah W.E.I., Cobbina J. and Kubota D. (2001). Integrated Watershed Management of Inland Valley - Ecotechnology Approach. Proc. Int. Workshop by Japan International Cooperation Agency \& Crops Research Institute, Ghana, 6-8 Feb. 2001. 203 pp.

Witt C., Dobermann A., Buresh R., et al. (2005). Sitespecific nutrient management and the sustainability of phosphorus and potassium supply in irrigated rice soils of Asia. In: Proc. Rice Res. Conf., IRRI (pp. 360-363). www.agric.gov.ab.cal/department/dept.docs.ns 